\title{
Massive stocking with hatchery larvae may constrain natural recruitment of whitefish stocks and induce unwanted evolutionary changes
}

\author{
Reiner Eckmann*
}

\begin{abstract}
The stocking of hatchery-produced whitefish is a common practice in most countries of the species' natural range. Rigorous monitoring of the effects of stocking is less common, however, and possible negative impacts of stocking on the target population are rarely considered, even though supportive stocking might exert a series of negative effects. The present study discusses these potential impacts, taking Upper Lake Constance whitefish as an example. In 2003, a proportion of the larvae stocked into the lake were labelled with Alizarin Red S. The contribution made by stocking to virtual cohort size was estimated at $83 \%$. Survival rates from egg or larval stages to adulthood for naturally produced fish and those incubated in hatcheries in 2003 were compared with those estimated from records pertaining to the cohorts of 1925-1939. Survival rates for lake-hatched larvae in 2003 fell between 1 and $10 \%$ of historic values. Several factors that may have contributed to this decline are discussed, of which the most potent seems to be the massive stocking of the lake with delayed hatchery larvae. Continued successful stocking will increase the contribution to the population of fish with partial or complete hatchery ancestry, and it may compromise the stock's ability to adapt to a changing environment through natural selection.
\end{abstract}

Keywords: Alizarin, cold incubation, Coregonus fisheries-induced evolution, year-class strength.

\section{Introduction}

The stocking of hatchery-produced fish into natural water bodies is a common practice in many countries. The aims of stocking include the establishment of a species where it did not previously occur; the re-establishment of a species that has become extinct; the augmentation of populations where natural recruitment is deficient; the enhancement of fishery yield through increased cohort size; and the stabilisation of fluctuating fishery yields through reduction of year-to-year variations in cohort size. Once the aim of stocking has been clearly defined, the stocking program can be designed to best fulfil its aim. Consistent monitoring of

\section{Authors' address:}

Limnological Institute, University of Konstanz, Germany.

* Corresponding author, e-mail: reiner.eckmann@uni-konstanz.de 
stocking success is necessary in order to optimise procedures and is particularly important if fishery managers wish to avoid a situation where stocking is a matter of routine rather than best practice.

Unregulated stocking brings several potential disadvantages to both the target population and the wider fish community (PEARsons 2010). The massive promotion of one species may be at the expense of others through increased competition for resources or enhanced predation pressure. Genetic diversity in the target population may be reduced and locally adaptive phenotypes may be compromised by the artificial selection of breeders from the resident population or by the acquisition of stocking material from outside the drainage basin. Where stocking programs are implemented in order to stabilize or increase yields, the costs can exceed the benefits.

Upper Lake Constance (ULC), which supports a long-standing commercial fishery for European whitefish (Coregonus lavaretus (L.)), is an ideal location to study the effects of a long-term, massive stocking program and to assess the value of continuing these activities into the future. The practice of stocking whitefish began in Lake Constance as early as 1887 (Rösch 1993). The number of larvae stocked into ULC per year ranged from 10 to $30 \cdot 10^{6}$ until the $1950 \mathrm{~s}$, then increased to around $350 \cdot 10^{6} \Leftrightarrow 7.4 \cdot 10^{3}$ larvae $^{\cdot}$ ha $\left.^{-1}\right)$ per year by the end of the $20^{\text {th }}$ century. Within the last 20 years, all six hatcheries on ULC began using cooled water to delay hatching of larvae by four to eight weeks. Today, most larvae are released into the lake immediately after hatching between mid-March and the end of April, while naturally spawned eggs will have hatched by mid-February. About $1 \%$ of artificially hatched larvae are given a further boost by being retained in the hatcheries for some weeks before stocking and pre-fed with lake plankton or dry feed.

The aims of whitefish stocking in ULC have varied over time, but have rarely been explicitly defined and there have been no rigorous monitoring efforts by which to evaluate success. Evidently, the principle motivation has been the enhancement of fishery yield, by circumventing perceived limits on cohort sizes such as insufficient hatching success in the wild (to be countered by artificial incubation of eggs) and a presumed mismatch between supply of and demand for planktonic larval food (to be corrected by delayed hatching).

During the second half of the $20^{\text {th }}$ century, the obvious deterioration of spawning habitat quality as a consequence of anthropogenic eutrophication gave further weight to the perceived value of stocking. Enhanced primary and secondary production caused greater sedimentation of organic matter to the lake bottom, and caused reduced oxygen concentration at the sediment-water interface (IGKB 2004), which created conditions likely to impair the embryonic development of pelagic spawning whitefish (MülLER \& STADELMANN 2004). Stocking may have helped prevent low year-class strength (YCS) in the most eutrophic years, although this has never been verified. Since the beginning of the $21^{\text {st }}$ century, oligotrophic conditions comparable to those in the 1950 s prior to anthropogenic eutrophication have been restored to ULC, and the development rate of whitefish eggs on the lake bottom has improved considerably (WAHL \& LÖFFLER 2009).

Supportive stocking has a long tradition in most countries of the native whitefish range (ECKMANN et al. 2007a). Of numerous attempts to evaluate the effects of stocking larvae on YCS or on yields, the results have consistently indicated little impact or the effects could not be demonstrated unequivocally (EcKmann et al. 1988; Gerdeaux \& Dewaele 1986; KieIn 1988; STEFEns 1995; TuRKOwSKI \& Bonar 1995). Stocking with whitefish juveniles, on the 
other hand, has been shown to increase harvests (Champigneulle \& Gerdeaux 1992; GerDEAUX 2004; Leskel.ä et al. 2004; SALOJärVI 1988; SALONEN et al. 1998). None of these studies, however, compared actual survival rates of hatchery and naturally produced larvae with stocking and yield records dating from periods when stocking intensity was much lower.

The aim of the present study was to evaluate the impact of the massive and ongoing ULC whitefish stocking programme on the whitefish's natural reproduction and on the stock's ability to adapt to a changing environment through natural selection. The results should help to refine the aim of continued stocking or challenge this costly endeavour. To this end, the contribution of stocked whitefish to the pelagic spawning cohort of 2003 was analysed, and actual survival rates for hatchery- and lake-born larvae were compared with historical data from the $1920 \mathrm{~s}$ and $1930 \mathrm{~s}$.

\section{Material and methods}

Lake Constance is the second largest pre-alpine lake in Europe. The lake is made up of two basins: Upper Lake Constance (ULC) with $473 \mathrm{~km}^{2}$ surface area and $101 \mathrm{~m}$ average depth and smaller and shallower Lower Lake Constance. Following a period of anthropogenic eutrophication (cf. Bäuerie \& GAEDKE 1998) the lake returned to oligotrophic conditions by the end of the $20^{\text {th }}$ century (ULC total $\mathrm{PO}_{4}-\mathrm{P}$ during spring turnover declined from $87 \mu \mathrm{g} \mathrm{L} \mathrm{L}^{-1}$ in 1979 to $7 \mu \mathrm{g} \mathrm{L}{ }^{-1}$ in 2008). European whitefish is the dominant fish species in ULC accounting for $>80 \%$ of commercial haryests (EcKMANN \& RöscH 1998). Six hatcheries bave incubated around $7000 \mathrm{~L}$ of whitefish eggs each year during the last ten years. Eggs and milt are obtained from ripe-and-rumning fish which are harvested from ULC during spawning time late November/early December. With an average hatching success of $70 \%$, these facilities contribute approximately 350 million recently hatched larvae plus an additional three to five million pre-fed larvae to the ULC stock each year.

In March 2003, 600 L of hatchery whitefish eggs were labelled with Alizarin Red S (ARS) (cf. ECKMANN 2003), and in April of the same year, 40 million labelled larvae were stocked into ULC shortly after hatching, corresponding to around 10\% of all larvae (labelled and unlabelled) stocked that year. In autumn 2003,290 young-of-the-year whitefish were sampled by trawling and their otoliths inspected for ARS marks (ECKMANN et al. 2007b). To obtain a second estimate of the fraction of hatchery-reared fish in the 2003 cohort, pelagic spawning whitefish were sampled with gillnets in December 2006 shortly before spawning. These fish were aged from scales by two independent readers, and otoliths (sagittae and lapilli) from age-3 fish were secured for analysis. Otoliths were embedded in expoxy resin, ground close to the nucleus and examined under an epifluorescent microscope (Zeiss filter set no, $487915,546 \mathrm{~nm}$ excitation wavelength) for ARS marks in the otolith nucleus by two independent readers. Grinding the sagittae of fish $>30 \mathrm{~cm}$ in total length close to the nucleus proved difficult due to their size and irregular shape, so ultimately only the lapilli were used for this analysis. ARS marks were clearly recognizable and false positive detections can be emphatically ruled out because in larvae treated at the time when the otoliths started to form, only the otolith primordia were stained (ECKMANN 2003). Thus, any fluorescence caused by irregular structures or cracks in the otoliths could be distinguished clearly from true ARS marks.

In order to compare numbers of hatchery-incubated eggs with those spawned naturally, a virtual population analysis was used to back-calculate the number of females per year-class which had spawned that winter, assuming a balanced sex ratio in the population (THOMAs \& EcKMANN 2007). Age-specific fecundity was determined by M. KugLer (Wildlife and Fishery Administration of the Canton of St. Gall, Switzerland) from females sampled before the onset of the 2002 spawning season. Entire ovaries were excised and weighed (to $0.1 \mathrm{~g}$ ) and a $12.5 \%$ reduction was made to account for the weight contributed by ovarian tissue (determined empirically in a separate analysis by M. KUGLER). A subsample of eggs was enumerated per female and weighed (to $1 \mathrm{mg}$ ), allowing the total number of eggs per ovary to be calculated. 
The potential impact of continued supportive stocking on the target population was estimated by calculating the ancestry of whitefish after two generations under the following assumptions: (i) naturally recruited and stocked fish have similar survival, (ii) they mature at the same age, (iii) they have the same probability of being canght in the spawning fishery, and (iv) reproduction is random both in the lake and in hatcheries. The percentage contribution of hatchery-bred fish was held constant across generations, i.e., the parent and all following generations comprised $80 \%$ of hatchery-bred fish.

\section{Results}

Of the 294 fish sampled in December 2006, 252 individuals ranging from 30 to $40 \mathrm{~cm}$ total length belonged to the 2003 cohort. Among these age- 3 fish, 21 individuals $(8.3 \%)$ had ARSlabelled lapilli (Table 1). To estimate the proportion of stocked fish in the 2003 cohort, the four independent samples shown in Table 1 were pooled. This is justified as the labelled larvae were distributed widely during stocking, so it can be safely assumed that the samples were drawn from a well-mixed stock. Because ARS-labelled individuals accounted for only around $10 \%$ of all larvae stocked in 2003, we would expect to find 210 fish among 252 individuals if all stocked fish had been labelled. The $95 \%$ binomial confidence interval of the $83 \%$ hatchery contribution to the cohort was calculated as $78-88 \%$, based on 210 labelled fish out of 252 . The sex ratio in the sample of age- 3 fish was biased in favour of males by 1.6:1, but the proportion of labelled fish did not differ between sexes $\left(\chi^{2}=0.340, P=0.560\right)$. When fish were grouped into two length classes ( $\leq 35 \mathrm{~cm}$ and $>35 \mathrm{~cm}$ total length), each of these contained a similar percentage of labelled fish $\left(\chi^{2}=0.287, P=0.592\right)$.

The total number of female whitefish present during the 2002 spawning season was around $1.8 \times 10^{6}$ individuals (Table 2). Age-specific fecundity for age-2 to age-6 whitefish ranged from 13870 to 16850 (Table 2). Thus, around $26 \times 10^{9}$ eggs were spawned in the lake, while only $4.8 \times 10^{8}$ eggs ( $1.8 \%$ of the total number of eggs laid in December 2002) were incubated in hatcheries. Of the latter, around $80 \%$ hatched into larvae $\left(3.8 \times 10^{8}\right.$ individuals), which were stocked in spring 2003 . The virtual size of the 2003 cohort, i.e., the total number of fish harvested in the fishery until the cohort was fished out, was approx. 750000 individuals. Based on the estimate that $83 \%$ of the virtual 2003 whitefish population are of hatchery origin, the survival rate to age- 3 of eggs incubated in hatcheries is $0.13 \%$, while for naturally spawned eggs it is $0.0005 \%$. Survival rate from egg to commercial size is therefore about 265 times higher for eggs incubated in hatcheries in 2003 than for eggs spawned in the lake that same year.

Table 1. ARS-labelled whitefish among 252 fish of the cohort 2003, sampled in December 2006 from the pelagic zone of ULC shortly before spawning.

\begin{tabular}{lrcccc}
\hline Date & $n$ & \multicolumn{1}{c}{ o/ 9} & Total length [cm] & \#ARS-labelled & \% ARS-labelled \\
\hline Dec. 07 & 72 & $55 / 17$ & $31.0-40.0$ & 3 & 4.2 \\
Dec.11 & 36 & $26 / 10$ & $32.0-39.0$ & 5 & 13.9 \\
Dec.15 a & 43 & $15 / 28$ & $31.0-39.0$ & 1 & 2.3 \\
Dec. 15 b & 101 & $57 / 44$ & $31.0-38.5$ & 12 & 11.9 \\
\hline & 252 & $153 / 99$ & & 21 & 8.3 \\
\hline
\end{tabular}

$a, b$ : samples taken from different fishing sites 
Table 2. Composition by age-classes of the pelagic spawning whitefish population in ULC in December 2002 estimated by virtual population analysis, age-specific fecundity, and the total number of eggs spawned by these fish in the lake, assuming a balanced sex ratio.

\begin{tabular}{lcccc}
\hline Age-class & $\begin{array}{c}\text { Virtual pop. } \\
\text { size }\left[* \mathbf{1 0}^{3}\right]\end{array}$ & $\begin{array}{c}\text { \# females used in } \\
\text { fecundity analysis }\end{array}$ & $\begin{array}{c}\text { Number of eggs } \\
\text { per female }\end{array}$ & $\begin{array}{c}\text { Total number of eggs } \\
\text { spawned }\left[* \mathbf{1 0} \mathbf{0}^{\mathbf{*}}\right]\end{array}$ \\
\hline 2 & 1,482 & 4 & 13,870 & 10.3 \\
3 & 1,297 & 9 & 14,950 & 9.7 \\
4 & 639 & 10 & 16,570 & 5.3 \\
$\geq 5$ & 97 & 12 & 16,850 & 0.8 \\
\hline
\end{tabular}

\section{Discussion}

Lake whitefish of the 2003 cohort that were labelled with ARS during embryonic development could be reliably identified at the end of their fourth year of life, allowing the contribution of hatchery larvae to the commercial yield to be estimated for the 2003 cohort. The estimate of $83 \%$ with a very narrow $95 \%$ binomial confidence interval of $78-88 \%$ is higher, albeit not statistically significant, than that obtained in autumn 2003 (62\% with confidence interval of $42-79 \%$ ) when young-of-the-year whitefish were inspected for ARS marks (ECKMANN et al. 2007b). The likely difference between the two estimates may be due to better survival of hatchery (including ARS-labelled) fish compared with naturally recruited fish between one and four years of age. But because cohort size for whitefish is mainly determined during the larval and early juvenile stage (ECKMANN \& PUSCH 1991; LeHTONEN et al. 1995), this seems unlikely. A more parsimonious explanation is that Lake Constance whitefish fall into two ecotypes, namely pelagic spawning "Blaufelchen" and inshore spawning "Gangfisch" (EcKMANN \& Rösch 1998). As both ecotypes seem to coexist in the pelagial during the growing season, young-of-the-year whitefish, which were trawled from the pelagial of ULC in autumn 2003, probably comprised juveniles of both forms, biasing the estimate of Blaufelchen from hatcheries towards low values. In 2006 however, fish were sampled from the pelagic zone in December, shortly before spawning. Therefore, only pelagic spawning whitefish were analyzed for ARS marks and the contribution of hatchery-produced Blaufelchen to the commercial stock will have been rated higher.

A sex ratio biased in favour of males is a common phenomenon with lake whitefish around spawning time because males arrive earlier at the spawning site (in the case of pelagic spawning Blaufelchen this being the upper $10 \mathrm{~m}$ of water) and remain there longer than females, which retreat to greater depths as soon as they are spawned out (ECKMANN 1991). However, the proportion of ARS-labelled fish did not differ between sexes or between length classes, suggesting that there is no sex-or length-based difference in the survival of marked fish.

The survival rate from egg to commercial size is more than two orders of magnitude ( 265 x) higher for eggs incubated in hatcheries than for naturally spawned eggs. The improvements in survival may be made during the egg stage from fertilization to hatching, and/ or during the period of development from larva to adult. Hatching success is surely higher in hatcheries where conditions for embryonic development are optimised. Total losses at 
this stage, including unfertilized eggs and deaths during embryogenesis, average $30 \%$ in the hatcheries at ULC, while in the lake, egg mortality based on dredge samples in winter 2000/2001, was estimated at 75\% (STRAILe et al. 2007). For the purpose of comparing recent and historic survival rates, lake-spawned egg mortality was set at $80 \%$ (cf. below). Applied to the estimate of eggs spawned naturally in the winter $2002 / 2003$ (cf. Table 2), this value implies that $5.2 \times 10^{9}$ larvae would have hatched in the lake. Survival from larva to commercial size would have amounted to $0.164 \%$ for hatchery larvae and to $0.002 \%$ for naturally produced larvae, a 67-fold difference.

The much-improved survival of larvae from hatcheries over those from the lake seems to support the assumption implicit in the practice of cold incubation: that a temporal mismatch exists between natural hatching date in the lake and temperature increase and/or maximal development of zooplankton in spring. If this was the case, we would expect that the low survival of larvae from the lake to be compensated for by the introduction of larvae from hatcheries, and particularly by larvae in which hatching was delayed. In other words, YCS should increase with the intensity of stocking. Yet a coarse comparison of YCS with stocking data over the past 50 years forces a rejection of this hypothesis (Fig. 1), despite the findings of a recent study of whitefish YCS in ULC (STRAILE et al. 2007), in which a significant influence of stocking on XCS was detected for a limited data set comprising the years 1962 1998. High levels of stocking, however, have not prevented strong fluctuations in YCS during the last 50 years (Fig. 1). The coefficient of variation of YCS was $82 \%$ for the $1920 \mathrm{~s} / 30 \mathrm{~s}$, as well as for the year-classes 1947-2003. Additionally, YCS was high in the 1950s when only limited stocking took place, so stocking alone cannot explain trends in YCS when considering the longer period from 1947 to 1998 (Straile et al. 2007). Between 1924 and 1938, when around 30 million larvae were stocked per year, YCS averaged $1.15 \times 10^{6}$ individuals. These values changed little over the last five decades of the $20^{\mathrm{th}}$ century, standing at $1.61 \times 10^{6}, 0.58 \times 10^{6}$, $1.14 \times 10^{6}, 1.21 \times 10^{6}$, and $1.66 \times 10^{6}$ individuals respectively. Thus, there is no evidence that increased stocking intensity and the implementation of cold incubation has had an effect on either absolute values or on year-to-year fluctuations in whitefish YCS.

Survival rates from the egg to commercial size in naturally recruited whitefish were estimated for the year-classes 1925 to 1939 in ULC by ELSTER (1944). These values averaged $0.019 \%$ when eggs laid by age- 2 females were included in the analysis, and $0.046 \%$ when these eggs, which were believed to be of lower quality, were excluded (ELSTER 1944). Compared with estimated survival rates for naturally spawned eggs of the 2003 cohort, historic survival rates (with and without eggs laid by age-2 females) were between 38 and 95 times higher than rates observed in the current study of the 2003 cohort. This large discrepancy may derive from differences in survival during the egg stage or during some later phase in life. Egg mortality estimated from dredge samples for the year-classes 1934, 1935 and 1940 ranged between 70 and $95 \%$ (ELSTER 1944), comparable to an estimate of $75 \%$ for the 2001 cohort (Straile et al. 2007). Even though these estimates have considerable uncertainty, they do suggest that differences between historic and recent rates of survival from egg to commercial size stem largely from mortality during larval and early juvenile development rather than during embryogenesis.

The chances of survival to commercial size for naturally recruited larvae can be estimated for both the $1920 \mathrm{~s} / 30 \mathrm{~s}$ and the 2003 cohort, assuming $80 \%$ egg mortality in both cases. With stocked larvae contributing $83 \%$ to the 2003 year-class, survival of lake-born larvae 


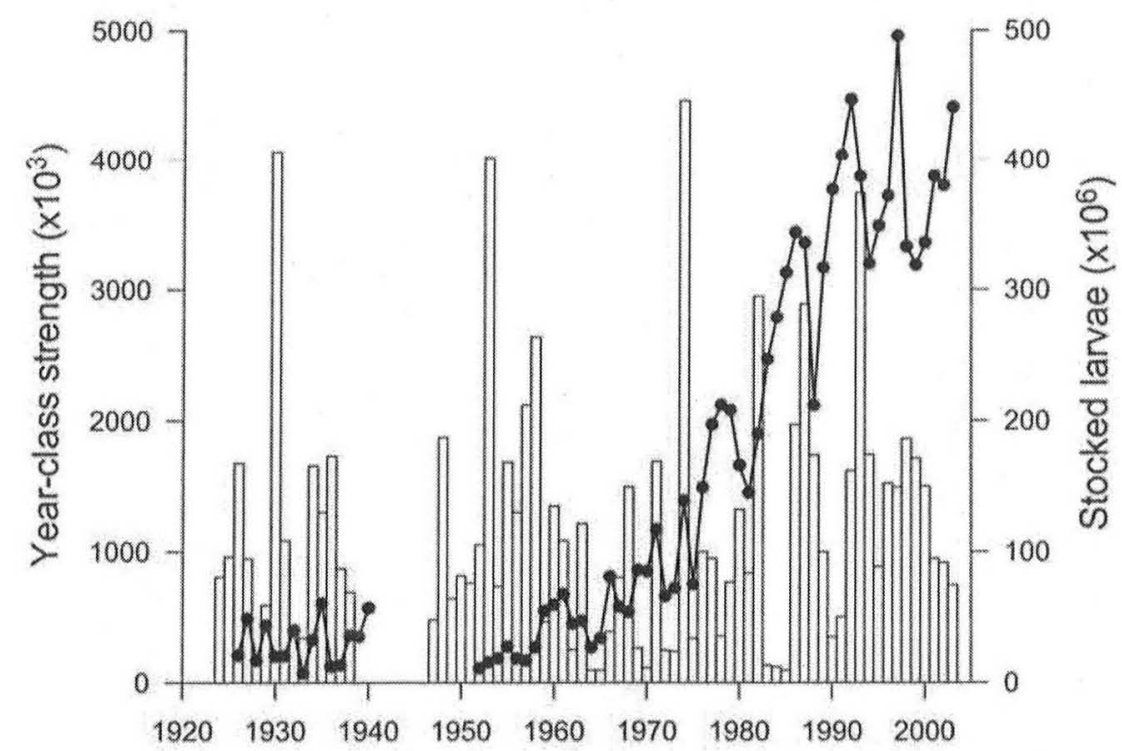

Fig. 1. Virtual year-class strength of pelagic spawning whitefish in Upper Lake Constance (bars), and number of larvae stocked into the lake (dots). Historic data are taken from ELSTER (1944); other data are from reports of the International Commission for Fisheries at Lake Constance.

was estimated at around $0.002 \%$. In the $1920 \mathrm{~s} / 30 \mathrm{~s}$, stocking intensity was $10 \%$ of what it is today, and delayed hatching had not been implemented. The contribution of stocking to YCS is therefore assumed to have been maximally $1 / 10$ of the 2003 estimate, i.e., $8.3 \%$. Under this scenario, survival of lake larvae would have ranged between 0.022 and $0.392 \%$ in these years. This suggests that survival of naturally hatched lake larvae in 2003 was between 10 and $1 \%$ of historic rates. Why was survival of naturally produced whitefish larvae so much lower for the 2003 cohort than during the early $20^{\text {th }}$ century? There are several possible factors that might contribute to an increase in larval mortality in recent years, and these will be dealt with in turn below.

Adult whitefish are the most likely predators of larval whitefish, followed by arctic charr (Salvelinus alpinus (L.)) and lake trout (Salmo trutta L.), whereas Eurasian perch (Perca fluviatilis $\mathrm{L}$.), the second most important commercial species, do not occur in the pelagic zone in spring and early summer. However, actual consumption rates have yet to be estimated, largely because of the difficulty in detecting easily digested larval remains in routine stomach content analysis. According to estimates by ELSTER (1944), the minimum January standing stock biomass of whitefish aged one year and older in the years 1925 to 1939 averaged 400 metric tons ( $\min .223$, max. 871), corresponding to $3.8 \times 10^{6}$ individuals ( $\min .23 \times 10^{6}$, max. $\left.5.9 \times 10^{6}\right)$. Estimates of the January stock for the years 1991 to 2000 averaged 973 metric tons (min. 308 , max. 1570), which corresponds to $5.3 \times 10^{6}$ individuals (min. $2.4 \times 10^{6}$, max. $7.0 \times 10^{6}$ ) (THOMAs \& ECKMANn 2007). Even allowing for less efficient fishing gear of the 1920 s and 1930 s, which may have led to stock levels being underestimated, the biomass of adult whitefish appears to be higher $(\times 2.4)$ at the end of the $20^{\text {th }}$ century, and these fish might 
have exerted a higher predation pressure on larvae hatched in the lake. Larvae from hatcheries will suffer from predation by larger whitefish as well, but they are exposed to predation risk for a much shorter time. This is so because hatchery larvae are stocked between four and eight weeks after natural hatching occurs when they encounter conditions that allow for faster growth, i.e., their mortality risk decreases faster than for larvae hatched in the lake.

Pathogens and parasites of larval whitefish are poorly studied in ULC, yet without more detailed studies there is no reason to assume incidence of diseases and parasitism is any higher today than in the past. The ruffe Gymnocephalus cernuus (L.), which became established in ULC in the $1980 \mathrm{~s}$, is known to prey on the eggs, but not the larvae, of littoral spawning whitefish (RösCH \& SCHMD 1996), but it has no influence on pelagic spawning whitefish eggs or larvae.

The dietary staples of larval whitefish are copepod nauplii, copepodites and adult cyclopoid and calanoid copepods (e.g. Hartmann 1986). During February and March 1935, the combined concentration of all these food items was about $10^{3}$ individuals $\times \mathrm{m}^{3}$ " in the depth of highest concentration" (ELSTER 1944), which corresponds roughly to a value of about $30 \times 10^{3}$ individuals $\times \mathrm{m}^{-2}$. Since the $1980 \mathrm{~s}$, average algal biomass in ULC has decreased concomitant with the almost linear decline in phosphorus concentration, but average zooplankton biomass lags behind. Zooplankton density in spring 2003 ranged from 100 to $200 \times 10^{3}$ individuals $\times \mathrm{m}^{-2}$ (IGKB 2004), suggesting that the food base for whitefish larvae is probably still better today than it was in the 1930 s.

According to data from a meteorological station at the southern shore of ULC, average annual air temperature has increased by $1.5^{\circ} \mathrm{C}$ from 1880 to 1997 . Increases have been most pronounced in winter, with averages for some months $2{ }^{\circ} \mathrm{C}$ higher in recent years (IGKB 2004). Because ULC is a warm-monomictic lake with holomixis in February, higher winter air temperatures translate into higher hypolimnetic temperatures, which will influence the rate of whitefish embryonic development during the following winter. Between 1947 and 1998 , temperature at $200 \mathrm{~m}$ depth fluctuated between 3.8 to $5.1^{\circ} \mathrm{C}$, resulting in egg development times between 65 and 87 days assuming that hatching occurs 330 degree-days after fertilization (STRALE et al. 2007). Because egg mortality due to predation has been considered a major factor influencing Lake Constance whitefish (NÜMANN \& Quoss 1972), earlier hatching of whitefish larvae should translate to improved survival to hatching (STRAnE et al. 2007). There is, however, no indication so far that the reduced survival of lake larvae described here (to between 10 to $1 \%$ of historic values), is linked to long-term changes in weather conditions.

The number of larvae stocked from hatcheries was more than an order of magnitude higher by the end of the century than in the years 1926-1940 (cf. Fig. 1). Furthermore, today almost all eggs are incubated at around $1{ }^{\circ} \mathrm{C}$ so that hatching is postponed by up to 2 months. The rationale for this costly procedure is that late larvae encounter better feeding conditions than early larvae, and this advantage should translate into better survival, and ultimately, improved YCS. It has already been shown that the latter expectation is not supported by the available data, and there now appear to be good reasons for discontinuing this practice.

None of the other mechanisms discussed so far can, alone or in combination, account for the extremely low survival rate of naturally recruited whitefish larvae in 2003 . However, the massive stocking of the lake with delayed larvae may constrain the survival of the former through competitive interaction. Prolonged incubation permits whitefish embryos to grow to 
larger size when released into the lake than naturally produced larvae (THOMAs \& ECKMANN 2012) which in turn allows for higher swimming speed and provides a greater gape width at the time of hatching. Even though delayed larvae have utilized part of their energy reserves for growth and maintenance metabolism during embryogenesis, the earlier hatched lake larvae will have already spent far greater energies during several weeks of constant swimming until filling of their gas bladder and spent greater energy by living at higher temperature (4$6{ }^{\circ} \mathrm{C}$ ) in the epilimnion. If feeding conditions do not allow the earlier hatched lake larvae to compensate for this higher energy expenditure, then late hatching larvae will have a competitive advantage at the time of their stocking into the lake. The presumably poorer condition of naturally recruited larvae compared with their hatchery-produced counterparts should not imply that a maturing cohort will automatically be strengthened by the addition of larvae in better condition. Rather than supplement the population hatched in the lake, stocked larvae seem to replace them through competitive exclusion/lower predation risk.

A model calculation revealed that a continued $80 \%$ contribution of hatchery-bred fish to the adult stock would eliminate almost all fish of pure lake ancestry after only two generations. Fish of one-third hatchery ancestry or less would make up less than $6 \%$ of the $\mathrm{F}_{2}$-generation while fish of two-thirds hatchery ancestry or more would contribute around $75 \%$ to the $\mathrm{F}_{2}$-generation. Hence, after only a few generations most of the fish would belong to lines in which the majority of ancestors have been incubated and hatched under controlled conditions.

When natural reproduction is successful - and dredge samples strongly indicate this to be the case in ULC - then stocking should be discontinued following the recommendations of a workshop on whitefish fisheries management (ECKMANN et al. 2007a) because the drawbacks of an ostensibly successful stocking program like the one at ULC are obvious. During artificial fertilization, mate choice is replaced by random mixing of eggs and milt (WEDEKIND et al. 2001), which are obtained from only a small fraction of the mature fish. During the 1980s and 1990 s for example, an average of $6 \%$ of mature fish were used to supply hatcheries at ULC with fertilized whitefish eggs (THOMAs et al. 2009). It is reasonable to assume that these $6 \%$ of spawners are not a random assortment of phenotypes (genotypes), and the risks of a genetic drift of so far unknown magnitude and direction should be carefully considered. Additionally, spawners are selected according to body girth by gillnets in the spawning fishery. When stocking is as successful as it appear to be, then the progeny of those females that invest more into reproduction, i.e., those with larger body girth, will be overrepresented in the next generation. Therefore, selection according to body girth can be a powerful mechanism for a sustained selection towards increased energy allocation to reproduction, which can only be achieved at the cost of somatic growth. As there is evidence already for fisheries-induced selection for slow growth by the gillnet fishery during the growing season (THOMAS \& ECKMANN 2007), the actual stocking practice might further enhance the selection for slow growth of lake whitefish.

Lake-spawned whitefish embryos develop under variable oxygen concentrations, and those that are more tolerant against low concentrations will have a competitive edge. If oxygen tolerance has a heritable component, these genotypes will be positively selected in the wild. In hatcheries, by contrast, where the eggs are bathed in oxygen-rich water until hatching, less oxygen-tolerant genotypes will be conserved. The longer a successful hatchery program is continued, the more of the maladapted genotypes will accumulate, and ultimately their progeny might underperform compared with those of naturally produced fish. 
In a changing environment, optimal adaptation through natural selection may become even more important in the future. Changes that may affect the whitefish in ULC as well as in many other pre-alpine lakes include (STRAIL et al. 2010): higher hypolimnetic temperatures, which will accelerate embryonic development; shifts in the timing of the spring zooplankton bloom in response to altered temperature regimes, which may create a mismatch with larval feeding requirements; reduced frequency of late-winter holomixis, which may put developing embryos at risk due to insufficient oxygen transport into the hypolimnion; and increased larval survival rates due to higher spring water temperatures, which may lead to larger cohort sizes and more intense competition for resources. If adaptation to these multifaceted changes is possible, it will only occur through natural selection, and not through random mixing of eggs and milt followed by incubation of eggs under strictly controlled conditions. A continuation of the apparently extremely successful stocking program in ULC will most likely result in the promotion of genotypes that are not optimally adapted to their environment.

If stocking is not discontinued as a precaution against its multiple risks - and it is unrealistic to expect that such a drastic measure will be adopted promptly by the managers of all bordering countries - it is important that the effects of this practice are at least scientifically monitored, so similar analyses of hatchery contribution to the adult stock are possible for future year classes.

\section{Acknowledgements}

Andreas Revermann, Langenargen and Rudi Wasem, Rorschach provided fish for otolith analysis in winter 2006. Myriam Schmid prepared and analyzed the otoliths. Special thanks to Michael Kugler, St. Gallen for determining age-specific fecundity of whitefish in winter 2006. I am greatful to Amy-Jane Beer for her comments and for improving the English.

\section{References}

BAUUERLE, E. \& GAEDKE, U. (1998): Lake Constance - characterization of an ecosystem in transition. Arch. Hydrobiol. Spec. Issues Advanc. Limnol. 53: 610 pp.

Champigneulle, A. \& Gerdeaux, D. (1992): Survey of experimental stockings (1983-85) of Lake Geneva with spring-prefed Coregonus Lavaretus fry $(3-4.5 \mathrm{~cm})$. - Pol. Arch. Hydrobiol 39: 721-729.

ECKMANN, R. (1991): A hydroacoustic study of the pelagic spawning behavior of whitefish (Coregonus lavaretus L.) in Lake Constance. - Can. J. Fish. Aquat. Sci. 48: 995-1002.

ECKMANN, R. (2003): Alizarin marking of whitefish, Coregonus lavaretus otoliths during egg incubation. - Fish. Manag. Ecol. 10: 233-239.

ECKMANN, R. \& PusCH, M. (1991); At what life stage is year-class strength of coregonids (Coregonus lavaretus L.) in Lake Constance determined? - Verh. Internat. Verein. Limnol. 24: 2465-2469.

EcKmann, R. \& Rösch, R. (1998): Lake Constance fisheries and fish ecology. - Arch. Hydrobiol. Spec. Issues Advanc. Limnol. 53: 285-301.

ECKMANN, R., GAEDKE, U. \& WETZLAR, H. J. (1988): Effects of climatic and density-dependent factors on year-class strength of Coregonus lavaretus L. in Lake Constance. - Can. J. Fish. Aquat. Sci. 45: $1088-1093$.

Eckmann, R., Gerdeaux, D., Mueller, R. \& Roesch, R. (2007a): Re-oligotrophication and whitefish fisheries management - a workshop summary. - Arch. Hydrobiol. Spec. Issues Advanc. Limnol. 60: $353-360$ 
ECKMANn, R., Kugler, M. \& RuHLE, C. (2007b): Evaluating the success of large-scale whitefish stocking at Lake Constance. - Arch. Hydrobiol. Spec. Issues Advanc. Limnol 60: 361-368.

ELSTER, H.-J. (1944): Üher das Verhältnis von Produktion, Bestand, Befischung und Ertrag sowie über die Möglichkeiten einer Steigerung der Erträge, untersucht am Beispiel der Blaufelchenfischerei des Bodensees. - Z. Fisch. Hilfswiss. 42: 169-357 [in German].

GERDEAUX, D. (2004): The recent restoration of the whitefish fisheries in Lake Geneva: the roles of stocking, reoligotrophication, and climate change. - Ann. Zool.Fenn. 41: 181-189.

GERDEAUX, D. \& DEWAELE, P. (1986): Effects of the weather and of artificial propagation on coregonid catches in Lake Geneva. - Arch. Hydrobiol. Ergebn. Limnol. 22: 343-352.

HARTMANN, J. (1986): Interspecific predictors of selected prey of young fishes. - Arch. Hydrobiol. Beih. Ergebn. Limnol. 22: 373-386.

IGKB (2004): Der Bodensee, Zustand-Fakten-Perspektiven. - IntemationaleGewässerschutzkommission für den Bodensee (IGKB), 2nd ed. Bregenz 2004, ISBN 3-902290-04-8: 177 [in German].

KLEIN, M. (1988): Significance of stocking for stabilising and increasing yields in the coregonid fishery in Lake Stamberg, FRG. - Finn. Fish. Res. 9: 397-406.

Lehtonen, H., Lappalainen, J., Leskel.̈, A. \& HudD, R. (1995): Year-class strength of whitefish, Coregonus lavaretus (L.), in relation to air temperature, wind, ice-cover and first year growth. - Arch. Hydrobiol. Spec. Issues Advanc. Limnol. 46: 229-240.

Leskelä, A., Jokikokko, E., Huhmarniemi, A., Simka, A. \& Savolainen, H. (2004): Stocking results of spray-marked one-summer old anadromous European whitefish in the Gulf of Bothnia. --Amn. Zool. Fenn. 41: 171-179.

Muller, R. \& Stadelmann, P. (2004): Fish habitat requirements as the basis for rehabilitation of eutrophic lakes by oxygenation. - Fish. Manag. Ecol 11: 251-260.

Numann, W. \& Quoss, H. (1972): Strudelwïrmer dezimieren den Felchenlaich - Ursachen für die unterschiedlichen Fangerträge in der Blaufelchen-Fischerei des Bodensees. - Fischwirt 22: 25-27 [in German].

PEARSONS, T. N. (2010): Operating hatcheries within an ecosystem context using the adaptive stocking concept. - Fisheries 35: 23-31.

Rösch, R. (1993): Fischbrutanstalten früher und heute. - In: KindLE, T. (ed.) Bodenseefischerei: Geschichte - Biologie und Okologie - Bewirtschaftung. - pp. 124-130, Jan Thorbecke Verlag, Sigmaringen [in German].

Rösch, R. \& Schmid, W. (1996): Ruffe (Gymnocephalus cernuus L.), newly introduced into Lake Constance: preliminary data on population biology and possible effects on whitefish (Coregonus lavaretus L.). - Ann. Zool. Femn. 33: 467-471.

SALOJÄRVI, K. (1988): Effect of the stocking density of whitefish (Coregonus lavaretus L. s.l.) fingerlings on the fish yield in Lake Peranka, Northem Finland. - Finn. Fish. Res. 9: 407-416

SAlonen, E., AHonen, M. \& MuteniA, A. (1998): Development of whitefish (Coregonus lavaretus) population and effects of large-scale compensation stocking in Lake Inari, northern Finland. - Arch. Hydrobiol. Spec. Issues Advanc. Limnol. 50: $439-448$.

STEFFENS, W. (1995): Yield and stocking of yendace (Coregonus albula) in northeast Germany. - Arch. Hydrobiol. Spec. Issues Advanc. Limnol. 46: 405-412.

Strame, D., Eckmann, R., Jungling, T., Thomas, G. \&, Lörrler, H. (2007): Influence of climate variability on whitefish (Coregonus lavaretus) year-class strength in a deep, warm monomictic lake. - Oecologia 151: 521-529.

Straile, D., Kerimoglu, O., Peeters, F., Jochimsen, M.C., Kummerlin, R., Rinke, K. \&, Rothhaupt, K.O. (2010): Effects of a half a millennium winter on a deep lake - a shape of things to come? - Global Change Biol. 16: 2844-2856.

ThOMAs, G. \& ECKMANN, R. (2007): The influence of eutrophication and population biomass on common whitefish (Coregonus lavaretus) growth - the Lake Constance example revisited. - Can. J. Fish. Aquat. Sci, 64: 402-410.

Thomas, G. \& EcKMANN, R. (2012) Reproduction vs. growth: indications for altered energy fluxes in Lake Constance whitefish through size-selective fishery. - Arch. Hydrobiol. Spec. Issues Advanc. Limmol. 63: 147-157. 
Thomas, G., Quoss, H., Hartmann, J. \& Eckmann, R. (2009): Human-induced changes in the reproductive traits of Lake Constance common whitefish (Coregonus lavaretus). - J. Evol. Biol. 22: $88-96$.

TURKOWSKI, K. \& BONAR, A. (1995): Effects of species composition and stocking on commercial catches of vendace, Coregonus albula (L.) in Ostróda lakes (northern Poland). - Arch. Hydrobiol. Spec. Issues Advanc. Limnol. 46: 397-403.

WAHL, B. \& LOFFLER, H. (2009): Influences on the natural reproduction of whitefish (Coregonus lavaretus) in Lake Constance. - Can. J. Fish. Aquat. Sci. 66: 547-556.

Wedekind, C., Muller, R. \& Spicher, H. (2001): Potential genetic benefits of mate selection in whitefish. - J. Evol. Biol. 14: 980-986. 